\title{
LEGUME COVER CROPS AND NUTRIENT CYCLING IN TROPICAL FRUIT TREE PRODUCTION
}

\author{
J. Lehmann* \\ Institute of Soil Science and Soil Geography \\ University of Bayreuth \\ 95440 Bayreuth, Germany, and \\ Federal Research Institute for Forestry \\ and Forest Products \\ 21027 Hamburg \\ Germany \\ *email: johannes.lehmann@uni-bayreuth.de
}

\author{
J.P. da Silva Jr., L. Trujillo \\ Embrapa-Amazônia Ocidental \\ Manaus, Brazil \\ K. Uguen \\ IRD Laboratoire d'Ecologie des Sols \\ Tropicaux \\ Paris, France
}

$\underline{\text { Keywords: competition, nitrogen, nutrient turnover, Pueraria phaseoloides }}$

\begin{abstract}
$\underline{\text { Abstract }}$
Legume cover crops have various important effects on nutrient cycling in tropical fruit tree production: they (i) fix atmospheric $\mathrm{N}_{2}$ and may amend the soil and trees with $\mathrm{N}$, (ii) recycle nutrients, and (iii) affect soil nutrient availability. Aboveground $\mathrm{N}$ accumulation usually is very large in legume cover crops as seen from Pueraria phaseoloides being 8 to 14 times higher than in intercropped fruit trees. Biomass production and $\mathrm{N}$ turnover will often exceed these values. Nutrient cycling may be significantly enhanced by the cover, leading to less nutrient leaching and higher nutrient contents in the topsoil, such as K. The amount of biological $\mathrm{N}$ fixation is an important factor for the $\mathrm{N}$ cycling. As a result, total soil $\mathrm{N}$ contents may often increase and $\mathrm{N}$ availability is enhanced. For nutrients other than $\mathrm{N}$ which cannot be supplied by the legume from external sources like $\mathrm{P}$, the cover crop may induce nutrient competition resulting in lower tree nutrition.
\end{abstract}

\section{$\underline{1 . \text { Introduction }}$}

Intercropping trees with cover crops is a well-known strategy in several cash-crop production systems in the tropics. In tropical Asia, cover crops are frequently planted in oil palm plantations (Broughton, 1976), as well as with coconut (Aldaba, 1995) and rubber (Watson, 1989a). Cover crops are also used in coffee production for example in Cameroon (Bouharmont, 1978), Kenya (Njoroge \& Kimemia, 1993) or Nicaragua (Bradshaw \& Lanini, 1995). Cover crops may fulfill several purposes in tree production systems which have long been recognized (Bunting \& Milsum, 1928). Through the permanent soil cover, erosion risk and therefore soil nutrient and organic matter losses can be decreased as well as soil structure can be improved (Lal et al., 1993).

However, the cover crop may also exert negative effects on tree performance. Competition for nutrients can reduce crop yields. If a vine is used as a cover crop, intensive management is needed to prevent it from climbing the trees (Watson, 1989a). The balance of beneficial and detrimental effects on fruit trees will determine the success of including a cover crop in the cropping system. These interactions of positive and negative effects were not adequately discussed up to now. Whereas ample information exists about cover crops in crop rotations (e.g. Barber \& Navarro, 1994a), forage legumes (e.g. Cadisch et al., 1989) or intercropping with annual crops (e.g. Tian et al., 1999), little information is 
available about cover crops in fruit tree production systems in the tropics apart from commercial tree crops like rubber (Watson, 1989a) or oil palm (Broughton, 1976). In this paper, we examine the effects of legume cover crops on nutrient cycling in tropical fruit tree production with special reference to Pueraria phaseoloides.

\section{Biomass production and nutrient turnover}

The importance of cover crops for the nutrient cycle of the whole fruit tree cropping system depends on how many and how fast the nutrients are recycled. The magnitude of nutrient cycling is a function of (i) the biomass production, (ii) the nutrient contents and (iii) the decomposition rate.

The aboveground biomass of cover crops can reach values similar to those of associated fruit trees or even exceed them as seen from Table 1. Even higher was the proportion of $\mathrm{N}$ accumulated in the aboveground biomass of Pueraria with $83 \%$ (Table 1), because of its high $\mathrm{N}$ content. Similarly in an oil palm plantation in Malaysia, the amount of $\mathrm{N}$ in the legume biomass was $82 \%$ of the total aboveground N (Agamuthu and Broughton, 1985). During the establishment of a guarana plantation (Paullinia cupana), N uptake of Desmodium ovalifolium with $169 \mathrm{~kg} \mathrm{~N}^{-1}$ was more than one order of magnitude higher than that of guarana with $4.4 \mathrm{~kg} \mathrm{~N} \mathrm{ha}^{-1}$ (Canto, 1989). Legumes generally have high foliar $\mathrm{N}$ contents typically ranging from 20 to $45 \mathrm{mg} \mathrm{g}^{-1}$. They are also rich in other nutrients like P, K and Ca (e.g. Szott, 1987).

Table 1 Aboveground biomass and $\mathrm{N}$ accumulation of a mixed fruit tree cropping system and a legume cover crop in the central Amazon; values in one column followed by the same letter are not significantly different at $\mathrm{P}<0.05$ ( $\mathrm{n}=9$ ) (from Lehmann et al., 1999b).

\begin{tabular}{lcccc}
\hline Species & $\begin{array}{c}\text { Biomass } \\
{\left[\mathrm{Mg} \mathrm{DM} \mathrm{ha}^{-1}\right]}\end{array}$ & $\begin{array}{c}\text { Proportion } \\
{[\%]}\end{array}$ & $\begin{array}{c}\text { Nitrogen } \\
{\left[\mathrm{kg} \mathrm{N} \mathrm{ha}^{-1}\right]}\end{array}$ & $\begin{array}{c}\text { Proportion } \\
{[\%]}\end{array}$ \\
\hline Pueraria phaseoloides & $8.8 \mathrm{a}$ & $61.5 \mathrm{a}$ & $350.3 \mathrm{a}$ & $83.1 \mathrm{a}$ \\
Theobroma grandiflorum & $4.4 \mathrm{~b}$ & $29.2 \mathrm{~b}$ & $46.3 \mathrm{~b}$ & $11.0 \mathrm{~b}$ \\
Bactris gasipaes & $1.4 \mathrm{c}$ & $9.3 \mathrm{c}$ & $25.0 \mathrm{c}$ & $5.9 \mathrm{c}$ \\
Total biomass & 14.6 & 100.0 & 421.6 & 100.0 \\
\hline
\end{tabular}

The nutrient accumulation within the biomass alone, however, does not give adequate information about the nutrient turnover, which is the relevant parameter for the magnitude of nutrient cycling. For this purpose, the biomass production has to be measured, which is more difficult for creeping legumes in comparison with trees. The biomass production may vary considerably throughout the year and is dependent on rainfall (Fig.1). At the onset of the rainy season, monthly biomass production was shown to reach the values of the standing biomass of the cover crop (Fig.1).

Similar to the aboveground biomass and nutrient accumulation, the turnover of cover crops is also very high in comparison to fruit trees, as shown for Pueraria in Table 2. Biomass production of the cover crop comprised $55 \%$ of the total biomass production of the system, with even $66 \%$ for N. Centrosema pubescens and Pueraria added $123 \mathrm{~kg} \mathrm{~N}$ $\mathrm{ha}^{-1} \mathrm{yr}^{-1}$ to the soil in an oil palm plantation, being double the amount of harvested bunches (Agamuthu \& Broughton, 1985). Mixtures of cover crops containing Pueraria 
had an annual leaf litter return of $150 \mathrm{~kg} \mathrm{~N} \mathrm{ha}^{-1}$ (calculated from Broughton, 1977) compared to only $44 \mathrm{~kg} \mathrm{~N} h a^{-1}$ of rubber stands (Watson, 1989b). These examples illustrate the importance of the cover crop for nutrient cycling in a fruit tree plantation.

The cycling of nutrients also depends on the rate of litter decomposition and nutrient release. Due to the high $\mathrm{N}$ contents and the low C-to-N ratio, litter decay is usually very rapid. However, also other parameters of litter quality may play an important role such as the lignin or polyphenol content. The high nutrient turnover through legume cover crops results in a rapid nutrient cycling. Thus, the topsoil under Pueraria was shown to contain a larger proportion of applied ${ }^{15} \mathrm{~N}$ than soils under the associated fruit trees (Lehmann et al., 1999b). Despite the higher $\mathrm{N}$ turnover and topsoil $\mathrm{N}$ contents (see below), the leaching losses of applied ${ }^{15} \mathrm{~N}$ under Pueraria were lower than under the trees, since the recovery approached zero in the subsoil at Pueraria sites (Lehmann et al., 1999b). Similarly, Agamuthu \& Broughton (1985) found reductions of leaching losses by $63 \mathrm{~kg} \mathrm{~N} \mathrm{ha}{ }^{-1} \mathrm{yr}^{-1}$ compared to bare soil in a legume-oil palm system in Malaysia. The increased nutrient cycling by using legume cover crops may also improve fertilizer use efficiency as shown in comparison to grass cover for an oil palm plantation in Malaysia (Broughton, 1978).

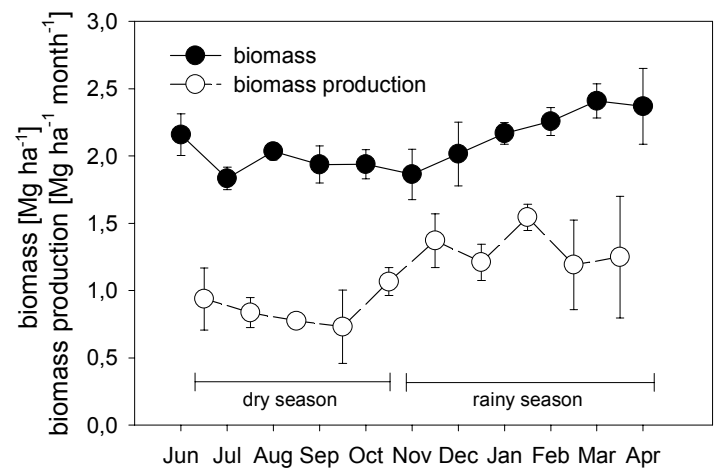

Fig. 1 Aboveground biomass and biomass production of Pueraria phaseoloides in the central Amazon; means and standard errors $(\mathrm{n}=3)$ (Uguen et al., unpubl. data).

Table 2 Biomass production and $\mathrm{N}$ turnover of a legume cover crop in comparison to fruit trees in central Amazonia (Uguen et al., unpubl. data; Lehmann et al., 1999b).

\begin{tabular}{lcccc}
\hline Species & $\begin{array}{c}\text { Biomass } \\
{\left[\mathrm{Mg} \mathrm{ha}^{-1} \mathrm{yr}^{-1}\right]}\end{array}$ & $\begin{array}{c}\text { Proportion } \\
{[\%]}\end{array}$ & $\begin{array}{c}\text { N-turnover } \\
{\left[\mathrm{kg} \mathrm{ha}^{-1} \mathrm{yr}^{-1}\right]}\end{array}$ & $\begin{array}{c}\text { Proportion } \\
{[\%]}\end{array}$ \\
\hline Pueraria phaseoloides & 5.1 & 55 & 212 & 66 \\
Theobroma grandiflorum & 1.2 & 13 & 21 & 7 \\
Bactris gasipaes & 3.0 & 32 & 90 & 27 \\
Total turnover & 9.3 & 100 & 323 & 100 \\
\hline
\end{tabular}

\section{Biological $\mathrm{N}$ fixation}

The $\mathrm{N}$ balance of a cropping system can be improved using legumes as a cover crop because they fix atmospheric $\mathrm{N}_{2}$. The magnitude of biological $\mathrm{N}$ fixation of legumes is highly variable and depends on several factors, such as plant species, inoculation, soil nitrate and water contents (Giller \& Wilson, 1991). Additionally, the experimental determination of biological $\mathrm{N}_{2}$ fixation poses large problems (Witty \& Giller, 1991). N fixation depends on soil water availability, and the proportion of fixed $\mathrm{N}$ in Pueraria can be shown to increase in the wet season (Table 3). $\mathrm{N}$ fixation was also reported to be strongly affected by the inorganic soil $\mathrm{N}$ content and reduced by $\mathrm{N}$ fertilization (e.g. Senaratne $e t$ 
al., 1987). In $\mathrm{N}$ poor soils, however, fixation of atmospheric $\mathrm{N}_{2}$ can be stimulated by low $\mathrm{N}$ doses (Streeter, 1988). $\mathrm{N}$ mineralization from litter decomposition may also affect $\mathrm{N}$ fixation, resulting in a lower proportion but a higher total amount of fixed $\mathrm{N}$ in Pueraria (Vesterager et al., 1995). The latter may also be an effect of a better supply of other nutrients through the litter. On acid tropical soils, the nodulation will strongly depend on the soil Ca, Mo and Al contents as shown by Andrew (1978).

The proportion of $\mathrm{N}$ fixation by Pueraria can reach up to more than $80 \%$ (Cadisch et al., 1989; Vesterager et al., 1995). In both the dry and wet season, the total amount of fixed $\mathrm{N}$ of Pueraria was a relevant addition to the cropping system in central Amazonia (Table 3), considering that e.g. Theobroma had a total aboveground $\mathrm{N}$ amount of only 46 $\mathrm{kg} \mathrm{ha}^{-1}$ (Table 1). Also in relation to the recommended fertilizer application of $15 \mathrm{~kg} \mathrm{~N} \mathrm{ha}^{-}$ ${ }^{1}$ in the same system, the fixed amounts are very high. Zaharah et al. (1986) reported a biological fixation of $151 \mathrm{~kg} \mathrm{~N} \mathrm{ha}^{-1} \mathrm{yr}^{-1}$ of Pueraria growing in a young oil palm plantation in Malaysia. During three months growth in a pot experiment, Joseph (1970) estimated the $\mathrm{N}$ fixation of Pueraria to $65 \mathrm{~kg} \mathrm{ha}^{-1}$.

Table 3 Proportion and total amount of biological N fixation of Pueraria phaseoloides determined by isotope dilution in central Amazonia (Silva Jr. \& Lehmann, unpubl. data).

\begin{tabular}{lcc}
\hline Season & Proportion $^{1}$ & $\mathrm{~N}$ amount \\
& {$[\%]$} & {$\left[\mathrm{kg} \mathrm{N} \mathrm{ha}^{-1}\right]$} \\
\hline Dry season & $9-37 \pm 11$ & $32-130 \pm 39$ \\
Wet season & $23-45 \pm 6$ & $81-158 \pm 21$ \\
\hline
\end{tabular}

a range is given due to calculation with three different reference plants

\section{Soil nutrient improvement by legume cover crops}

Despite the fact that the legume cover crops have a large biomass production and turnover, they are not likely to increase the soil organic matter content (Barber \& Navarro, 1994a). However, Tian et al. (1999) reported a lower soil organic matter decline with a Pueraria simultaneous cropping system than with conventional cropping in Nigeria. The reason for the frequently lacking effect on soil organic matter contents is the high quality of the plant material with high $\mathrm{N}$ contents, low C-to-N and polyphenol-to-N ratios as seen for Pueraria (Lehmann et al., 1999a). In contrast to the soil organic matter, an improvement of soil $\mathrm{N}$ contents is frequently observed (e.g. Watson et al., 1964; Lal et al., 1979), yet this increase will mostly be restricted to the topsoil (Lehmann et al., 1999b). Aya \& Lucas (1978) did not find an increase of soil N contents after Pueraria and doubted the positive effect of legumes on soil $\mathrm{N}$ contents. Often, total soil $\mathrm{N}$ contents may not be increased by legume covers, only the $\mathrm{N}$ availability. In comparison to secondary vegetation, soils under Pueraria were shown to contain equal amounts of $\mathrm{N}$ in the bulk soil, but the high $\mathrm{N}$ contents and low $\mathrm{C}$-to-N ratios in the particulate organic matter fraction indicated a higher $\mathrm{N}$ availability on an Amazonian Ferralsol (Lehmann et al., 1999a). Consequently, Schroth et al. (1999) found a significantly higher soil $\mathrm{N}$ mineralization with than without Pueraria at the same site.

Legumes do not provide nutrients other than $\mathrm{N}$ from external resources, and therefore the effects on these nutrient stocks will be limited. In an experiment in Bolivia, Barber \& 
Navarro (1994b) found a significant soil nutrient increase only with Dolichos lablab and only for $\mathrm{K}$ from 14 different cover crops. This was an effect of $\mathrm{K}$ translocation from the subsoil (Lal et al., 1993) which was also reported by other authors (e.g. Eckert, 1991; Smyth et al., 1991). Additionally, the nutrient availability can be influenced by recycling of applied or soil native nutrients from the topsoil. Thus, unfertilized Pueraria slightly increased readily and successively available $\mathrm{P}$ pools in comparison to primary and secondary forest sites (Lehmann et al., 1999c). The incorporation of recalcitrant nutrient pools into successively available organic pools through a rapid nutrient cycling may be an important service of the legume cover crop. The cover may also have an indirect impact on nutrient transformations through the change of the microclimate. Thus, cover crops may decrease nutrient mineralization in comparison to bare soil (Watson, 1989b).

\section{Cover crop effects on tree nutrition}

The question whether soil nutrient improvement and enhanced nutrient cycling due to a legume cover crop also improves tree nutrition, will depend on (i) the specific nutrient, (ii) the amount of native soil nutrients and (iii) the interface of cover crop and tree. Whereas a legume may improve the $\mathrm{N}$ nutrition of an associated fruit tree, results can be completely different for other nutrients, such as $\mathrm{P}, \mathrm{Ca}$, or $\mathrm{K}$. The cover has a very high nutrient uptake, and therefore nutrient competition is likely to occur especially at crop establishment. This could be verified in experiments with guarana (Paullinia cupana) intercropped with various cover crops in central Amazonia (Table 4). The N nutrition of the fruit trees slightly benefited from the association with Pueraria, whereas the $\mathrm{P}$ and also the $\mathrm{Mg}$ and $\mathrm{Ca}$ nutrition decreased due to competition between cover crop and the three-year old guarana. In a young guarana plantation at the same site, all nutrients contents decreased (Canto, 1989; Table 4). Bouharmont (1978) reported higher foliar N contents of coffee intercropped with Pueraria, Mimosa and Flemingia congesta than with non-legumes or without a cover crop. The cover crops had no effect on $\mathrm{P}$, but at some locations decreased foliar $\mathrm{K}$ and $\mathrm{Mg}$ contents. In Malaysia, the nutrition of oil palm could be improved with legume covers of Pueraria and Centrosema for N, P and Mn, whereas the foliar K, Mg and Ca contents decreased (Broughton, 1976).

Nutrient competition may decrease after the cover crop is established and the nutrients are mainly cycling between plant and soil. This would entail, however, that sufficient nutrients are present in the system, and the cover crop nutrient cycling does not sequester nutrients needed for tree growth. Therefore, fertilizer applications to the trees have to consider the nutrient uptake of the cover crop.

The effects of a legume cover crop will largely depend on the quantity and availability of soil nutrients. When $\mathrm{N}$ is in ample supply, the additional $\mathrm{N}$ from biological $\mathrm{N}$ fixation will not significantly improve tree $\mathrm{N}$ nutrition as shown with natural ${ }^{15} \mathrm{~N}$ abundance studies (Lehmann et al., 1999b). A low improvement of tree nutrition may also be caused by the fact that the trees do not reach the nutrients underneath the cover crop. The root activity between the tree rows may be too low to permit a relevant nutrient uptake. In the experiment with Theobroma and Bactris described earlier, only about $20 \%$ of the total $\mathrm{N}$ uptake of the fruit trees came from the area between the tree rows (Lehmann et al., 1999b). Considering that in most cases one third of the legume $\mathrm{N}$ derives from biological $\mathrm{N}$ fixation and is additionally diluted in the soil, the $\mathrm{N}$ benefit from atmospheric $\mathrm{N}_{2}$ can only be low. With prolonged legume cover, however, these values may increase. 
Table 4 Aboveground nutrient contents of fertilized Paullinia cupana (guarana) as affected by intercropping with various legume cover crops.

\begin{tabular}{lrrrrrl}
\hline Treatment & $\mathrm{N}$ & $\mathrm{P}$ & $\mathrm{K}$ & $\mathrm{Ca}$ & $\mathrm{Mg}$ & Source \\
& $-------------\left[\mathrm{mg} \mathrm{g}^{-1}\right]---------$ & \\
\hline Pueraria phaseoloides & $28.8 \mathrm{a}$ & $3.2 \mathrm{~b}$ & $10.2 \mathrm{a}$ & $4.0 \mathrm{a}$ & $1.5 \mathrm{a}$ & Trujillo \& Lehmann \\
Control (without cover) & $28.2 \mathrm{a}$ & $3.6 \mathrm{a}$ & $9.5 \mathrm{a}$ & $5.4 \mathrm{a}$ & $1.7 \mathrm{a}$ & (unpubl. data) \\
Mucuna conchinchinensis & 12.1 & 0.72 & 5.04 & 3.15 & 0.76 & Canto (1989) \\
Desmodium ovalifolium & 15.4 & 0.91 & 6.30 & 4.10 & 0.99 & Canto (1989) \\
Flemingia congesta & 18.1 & 1.12 & 8.35 & 4.88 & 1.26 & Canto (1989) \\
Control (without cover) & 23.0 & 1.39 & 9.10 & 6.15 & 1.50 & Canto $(1989)^{2}$
\end{tabular}

${ }^{1}$ foliar analysis; ${ }^{2}$ analysis of the whole aboveground biomass
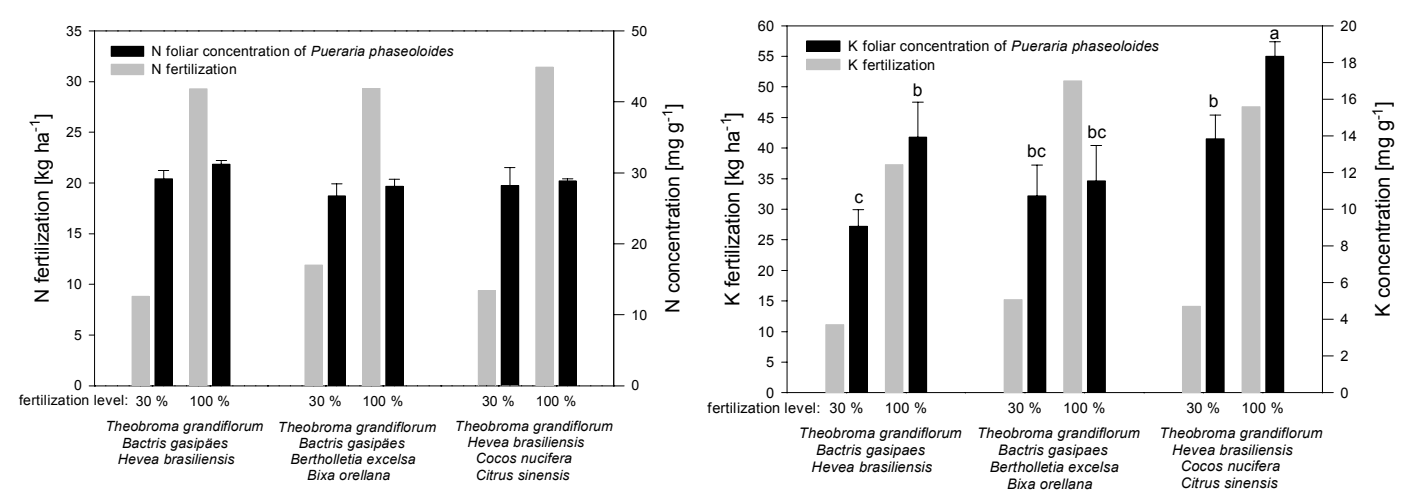

Fig. 2 Foliar N and P contents of Pueraria phaseoloides in relation to fertilizer applications and cropping system in the central Amazon; means and standard errors $(n=3)$; bars with the same letter are not significantly different at $\mathrm{P}<0.05$ (Silva Jr. \& Lehmann, unpubl).

\section{Management of cover crops for enhancing the nutrient benefit}

The effects of legume cover crops on nutrient cycling in tropical fruit tree production can be managed to increase the benefits and decrease constraints. The biomass production and hence nutrient turnover of the cover crop can effectively be increased by fertilization, and may be needed for young covers especially with respect to P (Watson, 1989a). In acid soils, liming may also be necessary for their establishment and optimal productivity (Andrew, 1978). Under on-farm conditions, fertilization of cover crops may often not be economically feasible, yet is done in intensive rubber production systems (Watson, 1989a). The cover crop may also profit from the fertilizer applied to the trees. In various mixed fruit tree systems in the central Amazon, fertilizer applications did not increase the foliar N contents of Pueraria, but its foliar K contents (Fig. 2). However, not only the amount of fertilizer applied to the trees may control the cover crop nutrition, but also the fertilizer placement and the nutrient uptake pattern of the fruit trees. The legume cover may also obtain more of the applied nutrients, if it grows directly underneath the canopy up to the tree stem. This would also enhance the possibility for the trees to benefit from the nutrient pool underneath the legume, especially with respect to N. However, if the 
cover crop is growing vigorously to the tree stem, the fruit tree may encounter competition for nutrients which may decrease its nutrition. Nutrient applications have to compensate for this effect. Apart from the nutrient aspect, a large problem of many cover crops is that they climb and then seriously damage the trees (e.g. Wilson et al., 1982). This can only be controlled by frequent cutting, which proves very labor intensive. Therefore, farmers' adoption of legume cover crops is often limited. This dilemma may be solved by selecting legume species which do not climb.

\section{References}

Agamuthu P. \& Broughton W.J., 1985. Nutrient cycling within the developing oil palmlegume ecosystem. Agric. Ecosys. Environm. 13: 111-123.

Aldaba F.R., 1995. Coconut production in the Philippines: problems and prospects. Plantations, Recherche, Développement Sept-Oct: 15-18.

Andrew C.S., 1978. Mineral characterisation of tropical forage legumes. In: Andrew C.S., \& Kemprath E.J. (Eds.), Mineral Nutrition of Legumes in Tropical and Subtropical Soils. Commonwealth Sci. Indust. Res. Org., Melbourne. pp. 93-112.

Aya F.O. \& Lucas E.O., 1976. A critical assessment of the cover policy in oil palm plantations in Nigeria. In: Earp D.A., \& Newall W. (Eds.), International Oil Palm Developments. Proceedings of the Intern. Oil Palm Conf., Kuala Lumpur. pp. 526-540.

Barber R.G. \& Navarro F., 1994a. Evaluation of the characteristics of 14 cover crops used in a soil rehabilitation trial. Land Degr. Rehab. 5: 201-214.

Barber R.G. \& Navarro F., 1994b. The rehabilitation of degraded soils in eastern Bolivia by subsoiling and the incorporation of cover crops. Land Degr. Rehab. 5: 247-259.

Bouharmont P., 1978. L'utilisation des plantes de couverture dans la culture du caféier robusta au Cameroun. Café Cacao Thé 22: 113-138.

Bradshaw L. \& Lanini W.T., 1995. Use of perennial cover crops to suppress weeds in Nicaraguan coffee orchards. Intern. J. Pest Manage. 41: 185-194.

Broughton W.J., 1976. Effects of various covers on the performance of Elaeis guineensis (Jacq.) on different soils. In: Earp D.A., \& Newall W. (Eds.), International Oil Palm Developments. Proceedings of the Intern. Oil Palm Conf., Kuala Lumpur. pp 501-525

Broughton W.J., 1977 Effect of various covers on soil fertility under Hevea brasiliensis Muell. Arg. and on growth of the tree. Agro-Ecosys. 3: 147-170.

Bunting G. \& Milsum J.N., 1928. Cover crops and green manures. Malayan Agric. J. 16: 256-280.

Cadisch G., Sylvester-Bradley R. \& Nösberger J., 1989. ${ }^{15} \mathrm{~N}$-based estimation of nitrogen fixation by eight tropical forage-legumes at two levels of P:K supply. Field Crops Res. 22: 181-194.

Canto A.C., 1989. Ecological importance of legumes as cover crops in guarana cultivation in the state of Amazonas. PhD thesis, University of Amazonas, Manaus. 121pp.

Eckert D.J., 1991. Chemical attributes of soils subjected to no-till cropping with rye cover crops. Soil Sci. Soc. Am. J. 55: 405-409.

Giller K.E. \& Wilson K., 1991. Nitrogen Fixation in Tropical Agroecosystems. CAB International, Wallingford. 189pp.

Joseph K.T., 1970. The effect of phosphorus on nitrogen fixation by the cover crop Pueraria phaseoloides on a latosol. The Planter, Kuala Lumpur 46: 153-156.

Lal R., Wilson G.F. \& Okigbo B.N., 1979. Changes in properties of an alfisol produced by various crop covers. Soil Science 127: 377-382. 
Lal R., Regnier E., Eckert D.J., Edwards W.M. \& Hammond R., 1991. Expectations of cover crops for sustainable agriculture. In: Hargrove, W.L. (Ed.), Cover crops for clean water. Proc. of the Conf. of the Soil \& Water Conservation Society. pp. 1-11

Lehmann J., Cravo M.S. \& Zech, W., 1999a. Single-tree effects on soil organic matter properties of a xanthic Ferralsol in the central Amazon. Geoderma: submitted.

Lehmann J., Silva Jr. J.P., Schroth G. \& da Silva L.F., 1999b. Nitrogen use of mixed tree crop plantations with a legume cover crop. Plant and Soil: submitted.

Lehmann J., Günther D., Mota M.S., Almeida M.P., Zech W. \& Kaiser K., 1999c. Singletree effects on soil P and S pools in a multi-strata agroforestry system. Agrofor. Syst.: submitted.

Njoroge J.M. \& Kimena, J.K., 1993. Current intercropping observations and future trends in arabica coffee, Kenya. Outlook on Agric. 22: 43-48.

Senaratne R., Amornpimol C. \& Hardarson G., 1987. Effect of combined nitrogen on nitrogen fixation of soybean (Glycine max L. Merill.) as affected by cultivar and rhizobial strain. Plant and Soil 103: 45-50.

Smyth T.J., Cravo M.S. \& Melgar, R.J., 1991. Nitrogen supplied to corn by legumes in a Central Amazon Oxisol. Trop. Agric. (Trinidad) 68: 366-372.

Streeter J., 1988. Inhibition of legume nodule formation and $\mathrm{N}_{2}$ fixation by nitrate. CSC Critical Rev. Plant Sci. 7: 1-23.

Szott L., 1987. Improving the productivity of shifting cultivation in the amazon basin of Peru through the use of leguminous vegetation. $\mathrm{PhD}$ thesis, North Carolina State University, Raleigh. 168pp.

Tian G., Kolawole G.O., Salako F.K. \& Kang B.T., 1999. Simultaneous cropping with Pueraria-legume cover crop: a soil fertility improvement technology without fertilizing. Plant and Soil: submitted.

Vesterager J.M., Osterby S., Jensen E.S. \& Schjoerring J.K., 1995. Symbiotic $\mathrm{N}_{2}$-fixation by the cover crop Pueraria phaseoloides as influenced by litter mineralization. Plant and Soil 177: 1-10.

Watson G.A., Wong P.W. \& Narayanan R., 1964. Effects of cover plants on soil nutrient status and on growth of Hevea. III Comparison of leguminous creepers with grasses and Mikania cordata. J. Rubber Res. Inst. Malaya 18: 80-95.

Watson G.A., 1989a. Field maintenance. In: Webster, C.C. (Ed.), Rubber. Longman Scientific, London. pp. 245-290.

Watson G.A., 1989b. Nutrition. In: Webster, C.C. (Ed.), Rubber. Longman Scientific, London. pp. 291-348.

Wilson G.F., Lal R. \& Okigbo B.N., 1982. Effects of cover crops on soil structure and on yield of subsequent arable crops grown under strip tillage on an eroded Alfisol. Soil Till. Res. 2: 233-250.

Witty J.F. \& Giller K.E., 1991. Evaluation of errors in the measurement of biological nitrogen fixation using ${ }^{15} \mathrm{~N}$ fertilizer. In: IAEA, Stable Isotopes in Plant Nutrition, Soil Fertility and Environmental Studies, Vienna. pp. 59-72.

Zaharah A.R., Sharifuddin H.A.H., Razley M.N. \& Mohd Saidi A.K., 1986. Measurement of nitrogen fixed by Pueraria phaseoloides by N-15 dilution technique. Pertanika 9: 45-49. 